\title{
AUTOMOTIVE INDUSTRY IN THE EUROPEAN UNION AND ITS COMPETITIVENESS IN THE WORLD
}

\author{
Milan Vošta ${ }^{1}$; Aleš Kocourek ${ }^{2}$ \\ Metropolitan University Prague, Department of International Relations and European Studies, \\ Dubečská 900/10, 100 31, Praha 10 - Strašnice, Czech Republic \\ e-mail: ${ }^{1} \underline{\text { milan.vosta@mup.cz; }}{ }^{2}$ ales.kocourek@mup.cz
}

\begin{abstract}
Over the last decade, the automotive industry has been one of the fastest growing branches of manufacturing. It became one of the most crucial industries in the European Union, but it also suffered significant structural and territorial transfers. Therefore, it seems crucial to test the competitiveness of the national automotive industries, analyse the long-term trends in Europe, put them into a global perspective, draft probable changes in the near future, and warn against the looming threats. The article uses methods of statistical analysis of long-term development of revealed symmetric comparative advantage index to search for continuous trends shaping the EU automobile production. It indicates the transfers of competitiveness from most of the traditional West European car producers in favour of the new EU member states, but also from the USA and Canada in favour of the new fast-growing developing countries and emerging markets. In the conclusion, authors provide a brief outline of the European Commission's response to these changes in form of the CARS 2020 Action Plan.
\end{abstract}

\section{Introduction}

The automotive industry has been one of the fastest growing branches of manufacturing industry over the last decade, but it also suffered significant territorial transfers during this period. Its importance for national economies of individual countries has been often crucial, as it goes beyond a single discipline through its extent, its number of jobs, its demands for metals and other materials, as well as through its links to other industries. It also features an extraordinary capital, production, and trading concentration. In the recent years, the processes of production have become more and more fragmentized and there has been a growing tendency to locate new production facilities outside the traditional production areas, to regions with more favorable production environment and large unsaturated markets. Recently, however, the automotive industry has been facing many serious issues. The car manufacturing in the European Union is not an exception. This sector of European industry was severely hit by the economic crisis in the years 2008 and 2009 and the following period has not brought the vital recovery to this region yet.

\section{$1 \quad$ Definition and Current Situation}

Automotive engineering is a part of the mechanical engineering and is also one of the most important branches of the engineering in general. According to the classification of economic activities, NACE (Nomenclature statistique des activités économiques dans la Communauté Européenne) Rev. 2 (2008) reported by Eurostat, the automotive industry is included in the section $\mathrm{C}$ - manufacturing, division 29 - manufacture of motor vehicles, trailers and semitrailers. This division is further broken down into the following groups: 29.1 Manufacture of motor vehicles, 29.2 Manufacture of bodies (coachwork) for motor vehicles, manufacture of trailers and semi-trailers, and 29.3 Manufacture of parts and accessories for motor vehicles 
[9]. This classification is in concordance with the Standard International Trade Classification (Rev. 3), where the section 7 (Machinery and transport equipment), division 78 (Road vehicles), group 781, 782, and 783 together correspond to NACE 29.1, group 784 corresponds to NACE 29.3, and group 786 corresponds to NACE 29.2 [8].

According to the Eurostat data, the EU automotive industry (NACE 29) consists of a total of 20,500 enterprises. The major share of the added value was generated by manufacture of motor vehicles $(64 \%)$, followed by the production of parts and accessories (33\%). Also the largest turnover in the automotive industry - over $71 \%$ - was generated by the segment of motor vehicles (526 billion euro). The remaining two segments are substantially weaker: The production of parts and accessories has a turnover of only 188 billion euro (25\%), the production of bodies, trailers, and semi-trailers only 3.4\%. Given the very broad and tight linkages of the automotive industry to other industries, the influence of the industry on job creation represents a major characteristics: The largest employer is the segment of manufacturing parts and accessories with a $46.5 \%$ share of total employment in the automotive industry, which proves the indispensable role of this particular segment in the entire industry. The production of automobiles accounts for $46.2 \%$ of jobs, while production of bodies, trailers, and semi-trailers has only a marginal importance when it comes to employment (7.3\%) [9]. According to some estimates, increase in sales by 1 million euro leads to the creation of approximately 10 new jobs in the automotive industry. The car production activity has an employment multiplier in the value of five (other industry activities in the value of three) [12].

\subsection{Current Situation in the World and in the European Union}

The European centre as a traditional car producer belongs still among the most important regions of automotive industry in the world. Nevertheless, its position has been gradually replaced by emerging, fast-growing markets, esp. those of eastern Asia, and Europe also falls short compared to the North American centre. The European share in the global car production is diminishing. In 2014, 17 million motor vehicles of all types were produced in Europe, which represents a 19\% share in the global production of nearly 90 million units [20].

The EU automotive industry employed a total of more than 13 million people in 2014. It is also necessary to mention the significant linkage between the automotive industry and nonmanufacturing sector. It is estimated that there are up to 10 million jobs in shops cars, spare parts, fuel, repair shops, rentals, and transportation. The largest employer in the automotive industry in the EU is by far Germany. Their automotive industry employs 749,000 workers in 43 factories. Germany is also the largest EU producer of cars (5.9 million motor vehicles in 2014), it generates the highest turnover and creates the largest added value among all the EU countries. The second largest EU producer of cars is Spain (2.4 million motor vehicles in 2014). The second largest employer in the EU is France with just 225,000 employees and with the third highest production (1.8 million motor vehicles in 2014). The third largest European employer is Italy with 171,000 workers, but the volume of car production ranks the country as low as the seventh position in the EU. The Czech Republic surpassed Italy in car production in 2009 and Slovakia in 2012. Given this recent development, a reduction in Italian employment in automotive industry can be expected in the near future. Other major EU countries, where the number of employees in the automotive industry exceeds 100,000 people, are: Poland, the United Kingdom, and Romania [16], [1]. 


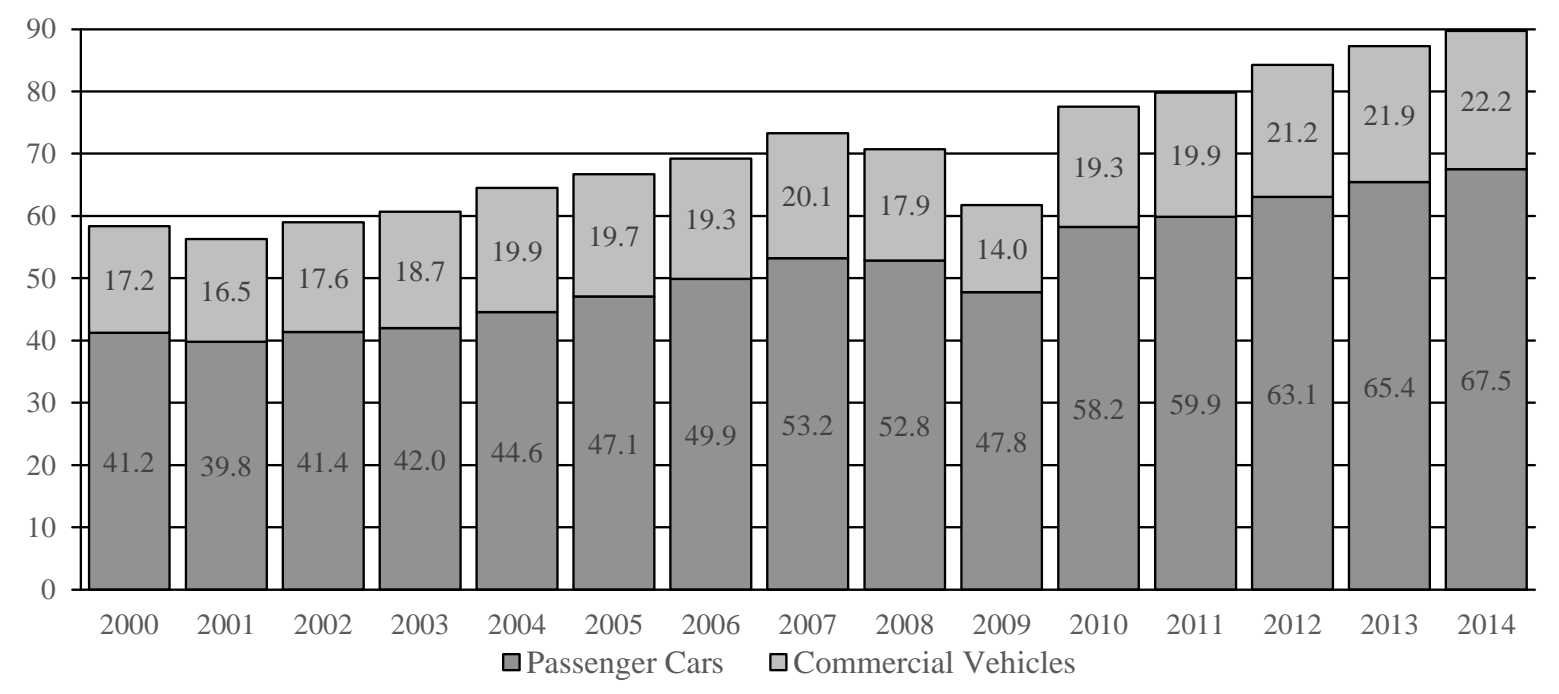

Source:based on data from [20]

Fig. 1: Worldwide automobile production from 2000 to 2014 (in million vehicles)

\subsubsection{Passenger Cars}

The global production of passenger cars has been recording an almost continuous growing trend (see Fig. 1). The slight decline in 2001 occurred due to the economic downturn in the USA, rising oil prices, and the restrictive policy of the European Central Bank. In subsequent years, production grew until 2007 to 53.2 million cars per year. During the crisis years of 2008 and 2009, the output of automotive industry declined to 47.8 million units. In 2010, however, there was a lively recovery and the boom has continued since then. In 2014, the annual pace of growth dropped to $3.2 \%$ and the world's production of passenger cars reached 67.5 million units [20].

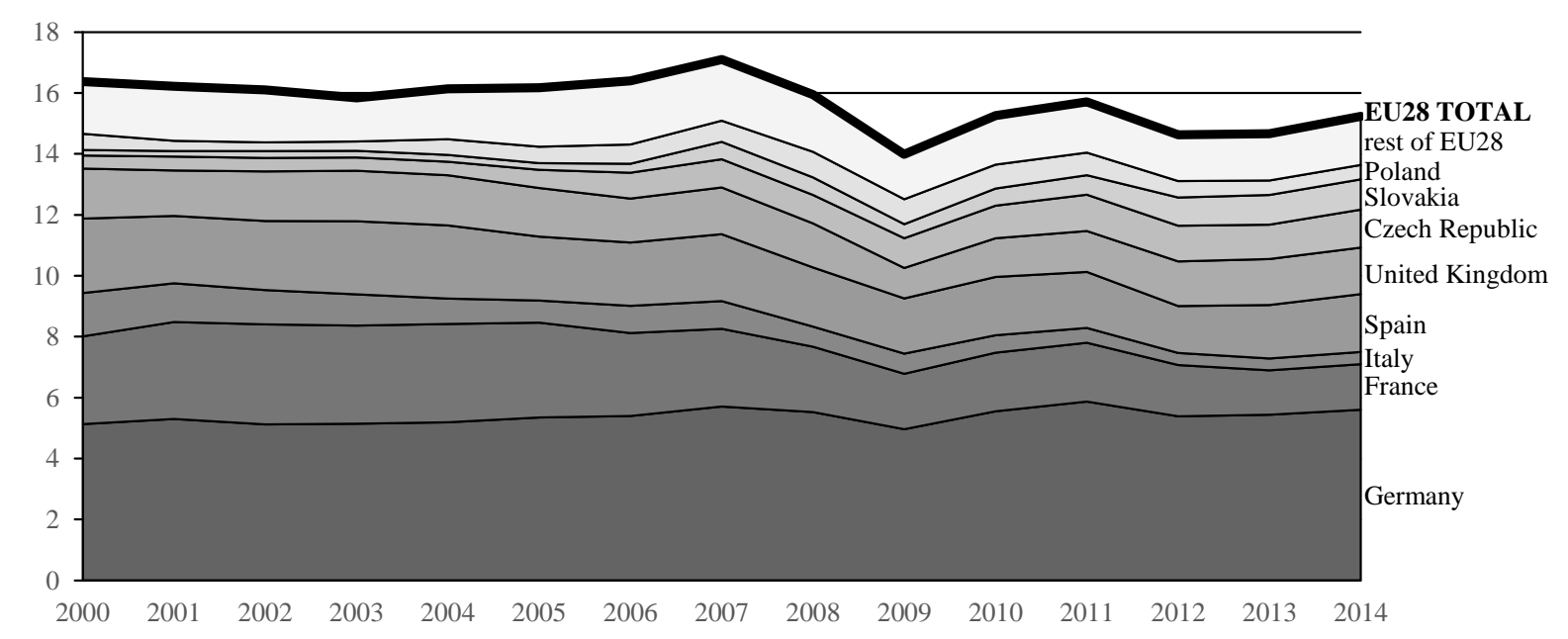

Note: All 28 current EU members are taken into account from 2000 to 2014.

Source: based on data from [16]

Fig. 2: Production of passenger cars in the EU28 from 2000 to 2014 (in million units)

In comparison with the world, the production of passenger cars in the European Union recorded a rather downward trend (see Fig. 2). In 2007, the EU produced over 17 million cars, but it has failed to even up this production so far. Despite generous stimulus measures ("scrapping bonuses"), the economic recession caused a big drop in production, down to 14 million in 2009. After a dynamic growth in 2010 and 2011 and a slight hang in 2012 and 2013, the production reached 15.2 million units in 2014. For illustration, the production of 
China in 2014 ran up by $10 \%$ to 19.9 million, Japan recorded 8.3 million, and the USA 4.2 million passenger cars [2]. Fig. 2 reveals long-term shifts in the passenger car production even within the EU. Especially the position of France and Italy was weakened in favour of the new member states, mainly the Czech Republic and Slovakia. Spain and the United Kingdom are more-or-less holding their positions, while Germany's passenger car production has been showing a mildly growing trend.

\subsubsection{Commercial Vehicles}

The world's production in the segment of commercial vehicles (i.e. light commercial vehicles, heavy trucks, and heavy buses) has not been growing at such a pace during the last 15 years (see Fig. 1). Similarly to passenger cars, also performance of commercial vehicle producers decreased in 2001. After a short recovery, the next decline took place already in 2005 and 2006 followed by a deep slump in 2008 and 2009, when the volume of production plummeted from the previous peak of 20.1 million to 14 million units. Unfavourable economic development and problems with sales affected the behaviour of corporations. They postponed investment which undercut the sales of commercial vehicles and together with the slowdown in demand for passenger cars resulted in vast staff reductions. Since 2010 the segment has been experiencing a period of growth globally, in 2012 the production exceeded the peak from 2007 and in 2014, they recorded the output of 22.2 million vehicles. The dynamics of the growth has been, however, slowing down from $6.3 \%$ in 2012 to $1.6 \%$ in 2014. [16]

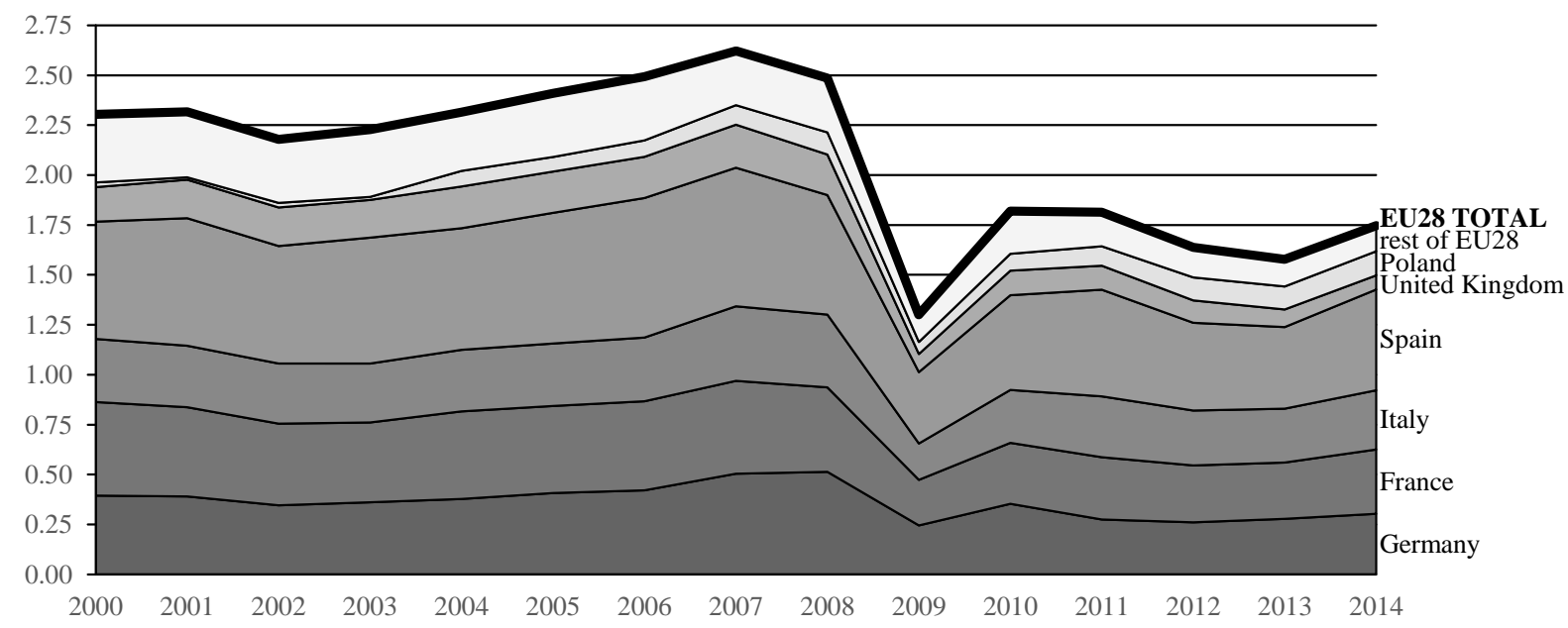

Note: All the 28 current EU members are taken into account from 2000 to 2014.

Source: based on data from [16]

Fig. 3: Production of commercial vehicles in the EU28 from 2000 to 2014 (in million units)

We can trace a very similar development in the EU in the period $2000-2009$ (see Fig. 3). The production of commercial vehicles culminated in 2007, when 2.6 million commercial vehicles were produced in the EU, while already the next year witnessed a decrease and in 2009 the number dropped to less than half of the 2007 output. Some recovery occurred in 2010, when the production of commercial vehicles reached 1.8 million units followed by another slowdown in 2012 and 2013. The more optimistic economic perspectives drew the production of this segment in the last year up to 1.75 units signaling a recovery of the sector.

Fig. 3 also illustrates a slowly growing share of commercial vehicles produced in Poland, probably taking the market positions of United Kingdom, and to some extent of France, and perhaps even Germany. 


\section{2}

Objective and Topicality of the Research

The automotive industry is one of the key industries in the European Union. More than 200 manufacturing and assembly plants in 2014 produced nearly 17 million vehicles [16]. The importance of the automotive industry can be also documented by its $7 \%$ share on the total GDP of the EU, 5.8\% share on the EU employment, and by a significant presence in exports (more than 6.5 million cars a year, Germany exports $77 \%$ of cars they produce) [12].

The different proportions in numbers of plants, shares of employment, volumes of production, and numbers of sales in different European countries, however, indicate, the competitiveness of individual EU member states is not at the same level and the automotive producers are exposed to tough competition not only on the world market, but also within the European Union. Therefore, it seems crucial to test the competitiveness of the national automotive industries, analyse the long-term trends in Europe and in the world, draft probable changes in the near future, and warn against the consequences and threats looming in the near future.

\section{$3 \quad$ Research Methods}

The concept of competitiveness has recently been widely discussed (for an overview see e.g. [13]) as a multi-criteria indicator of the conditions of a national economy [17]. On the level of the industry, however, the original, narrow, neoclassical concept of competitiveness seems more useful. Siggel [19] shows the distinction between competitiveness and comparative advantage, but even he admits the two theoretical concepts have in fact many features in common. Therefore, we follow the conception of competitiveness presented by Hindls et al. [11], who call a particular economic subject competitive if it is successful in penetrating the new markets and gaining a comparative advantage in international trade.

The research method of this paper is based on the methodology of revealed comparative advantage $(R C A)$ developed by Balassa [2]. It measures a country's export of a particular commodity in relation to its total exports and to the corresponding export performance of a set of countries. In other words, the $R C A$ is able to identify the sectors or commodities, with which the exporters of a particular country are more successful than the exporters from other countries.

$$
R C A_{i, t}^{C}=\frac{\frac{X_{i, t}^{C}}{\sum X_{t}^{C}}}{\frac{X_{i, t}^{G}}{\sum X_{t}^{G}}}
$$

where

$C$ is a country,

$G$ is a group of countries,

$i$ is a particular group or class of commodities (here a group 29.1 according to NACE Rev. 2), $t$ is a period of time.

The advantage of Balassa $R C A$ is the fact that it is not biased by changes in prices or exchange rates over time. In fact, it is a volume index. A problem with the Balassa $R C A$ is the asymmetry of its value: it varies from one to infinity for products in which the country has a revealed comparative advantage, but only from zero to one for commodities with a revealed comparative disadvantage. Resulting from Grupp [10], Dalum et al. [6] proposed a revealed 
symmetric comparative advantage index (RSCA) to alleviate the skewness problem as follows:

$$
R S C A_{i, t}^{C}=\frac{R C A_{i, t}^{C}-1}{R C A_{i, t}^{C}+1} .
$$

The closer to $\{+1\}$ the results of $R S C A$ get, the more significant are the comparative advantages they indicate, while the more they are converging to $\{-1\}$, the more substantial are the comparative disadvantages.

There has been an intensive debate on the explanatory power and unbiasedness of the $R C A$ and RSCA. Berkowitz et al. [4], Chor [5] as well as Barattieri [3] search for the sources of comparative advantages and demonstrate how transport cost, transaction cost or trade cost bias the results of the comparative advantage analyses. Moenius [14] proves RSCA is an adequate measure of comparative advantage, although it does not have a significant predictive power. Pingyao and Jingyun [18] perform the RSCA analysis to identify the growth potential of merchandise trade among the BRICS (Brazil, Russia, India, China, South Africa) countries and build further analytical instruments on the platform of RSCA. Wanling and Xiaohui [22] use the RSCA to detect the problems in bilateral relations between BRICS countries.

\subsection{Data and Countries}

The main source for the data on the exports of automotive products is the United Nations Conference on Trade and Development (UNCTAD) Statistical Division. The group of countries mentioned in equation (1) consists of 39 car producers listed by the International Organization of Motor Vehicle Manufacturers (Organisation Internationale des Constructeurs d'Automobiles, OICA), representing $99.24 \%$ of world car production (see Tab. 1) [16].

Tab. 1: OICA countries in order of total car production in 2014

\begin{tabular}{|c|c|c|c|c|c|c|c|c|}
\hline Country & CODE & Total & Country & CODE & Total & Country & CODE & Total \\
\hline China & $\mathrm{CHN}$ & $23,722,890$ & United King. & GBR & $1,598,879$ & Taiwan & TWN & 379,223 \\
\hline USA & USA & $11,660,699$ & Indonesia & IDN & $1,298,523$ & Uzbekistan & UZB & 245,660 \\
\hline Japan & $\overline{J P N}$ & $9,774,558$ & Czech Rep. & CZE & $1,251,220$ & Hungary & HUN & 227,030 \\
\hline Germany & DEU & $5,907,548$ & Turkey & TUR & $1,170,445$ & Australia & AUS & 180,311 \\
\hline South Korea & KOR & $4,524,932$ & Iran & IRN & $1,090,846$ & Portugal & PRT & 161,509 \\
\hline India & IND & $3,840,160$ & Slovakia & SVK & 993,000 & Austria & AUT & 154,340 \\
\hline Mexico & MEX & $3,365,306$ & Italy & ITA & 697,864 & Sweden & SWE & 154,173 \\
\hline Brazil & BRA & $3,146,118$ & Argentina & ARG & 617,329 & Slovenia & SVN & 118,591 \\
\hline Spain & ESP & $2,402,978$ & Malaysia & MYS & 596,600 & Finland & FIN & 45,035 \\
\hline Canada & $\overline{\text { CAN }}$ & $2,393,890$ & Poland & POL & 593,904 & Netherlands & NLD & 29,807 \\
\hline Russian Fed. & RUS & $1,886,646$ & South Africa & ZAF & 566,083 & Ukraine & UKR & 28,751 \\
\hline Thailand & THA & $1,880,007$ & Belgium & BEL & 516,832 & Egypt & EGY & 27,020 \\
\hline France & FRA & $1,817,000$ & Romania & ROM & 391,422 & Serbia & SRB & 10,675 \\
\hline
\end{tabular}

Source: [16]

\subsection{Analysis}

For the analysis, the individual RSCA for each of the listed 39 countries has been calculated in each year $(1995$ - 2014) for the NACE 29.1 group. The period was selected regarding the data availability and the statistical requirements. The export position (see Tab. 2) of each of 
these subjects was compared to the average of the group of 39 car producing countries. The positive result (see Fig. 4, vertical axis) therefore shows a global comparative advantage, while the negative result indicates a global comparative disadvantage of a particular country in comparison with basically all other possible global competitors.

Tab. 2: OICA countries in order of total car exports in 2014 (thousands of USD)

\begin{tabular}{|c|c|c|c|c|c|c|c|c|}
\hline Country & CODE & Total & Country & CODE & Total & Country & CODE & Total \\
\hline Germany & DEU & $182,371,363$ & Slovakia & SVK & $15,317,740$ & Portugal & PRT & $3,426,622$ \\
\hline Japan & JPN & $102,701,630$ & China & $\mathrm{CHN}$ & $14,297,893$ & Russian Fed. & RUS & $2,933,062$ \\
\hline United State & & $81,391,472$ & Netherlands & NLD & $13,011,570$ & Slovenia & SVN & $2,782,170$ \\
\hline Mexico & MEX & $61,334,642$ & Turkey & TUR & $12,733,080$ & Indonesia & IDN & $2,430,006$ \\
\hline South Korea & KOR & $51,793,407$ & Hungary & HUN & $11,240,532$ & Finland & FIN & $2,174,514$ \\
\hline Canada & CAN & $47,024,493$ & Poland & POL & $10,490,796$ & Australia & AUS & $1,825,216$ \\
\hline United King & GBR & $44,699,256$ & Sweden & SWE & $8,690,617$ & Serbia & SRB & $1,811,869$ \\
\hline Spain & ESP & $39,863,528$ & Argentina & ARG & $7,173,463$ & Taiwan & TWN & $1,326,951$ \\
\hline Belgium & BEL & $36,344,165$ & Austria & AUT & $6,916,470$ & Uzbekistan & UZB & 658,228 \\
\hline France & FRA & $27,127,546$ & India & IND & $6,792,223$ & Malaysia & MYS & 350,004 \\
\hline Czech Rep. & CZE & $18,865,432$ & South Africa & $\mathrm{ZAF}$ & $6,424,298$ & Iran & & 230,558 \\
\hline Italy & ITA & $17,654,788$ & Brazil & BRA & $5,591,816$ & Ukraine & UKR & 115,761 \\
\hline Thailand & THA & $16,950,477$ & Romania & ROM & $4,091,231$ & Egypt & EGY & 88,999 \\
\hline
\end{tabular}

In the next step, the mean annual pace of change over the 20-year-long (1995 - 2014) period has been estimated using ordinary least square correlation analysis (3). Since equation (3) estimates the slope of linear trend line over the period $1995-2014$, the auto-correlation is not an issue here.

$$
\beta_{1 i}^{C}=\frac{n \sum_{t=1}^{n} R S C A_{i, t}^{C} t-\sum_{t=1}^{n} R S C A_{i, t}^{C} \sum_{t=1}^{n} t}{n \sum_{t=1}^{n} t^{2}-\left(\sum_{t=1}^{n} t\right)^{2}},
$$

where

$C$ is a country,

$i$ is a NACE 29.1 group,

$t$ is a period of time, and

$n$ is a number of years (i.e. 20).

The values of $\beta_{1}$ were tested for statistical significance using T-test against $95 \%$ confidence level. Only the statistically significant values of $\beta_{1}$ were accepted for the following outcomes of the analysis. For a better and faster understanding, the most recent values of RSCA from the year 2014 were applied to the horizontal axis, while the estimated mean annual pace of change (the values of $\beta_{1}$ ) were brought to the vertical axis in the Fig. 4.

\section{$4 \quad$ Results and Discussion}

Only the group NACE 29.1 will be further discussed here, as it represents a predominant share of revenues and nearly a half of the automotive employment. The other two NACE 29 groups are a subject of further research. 


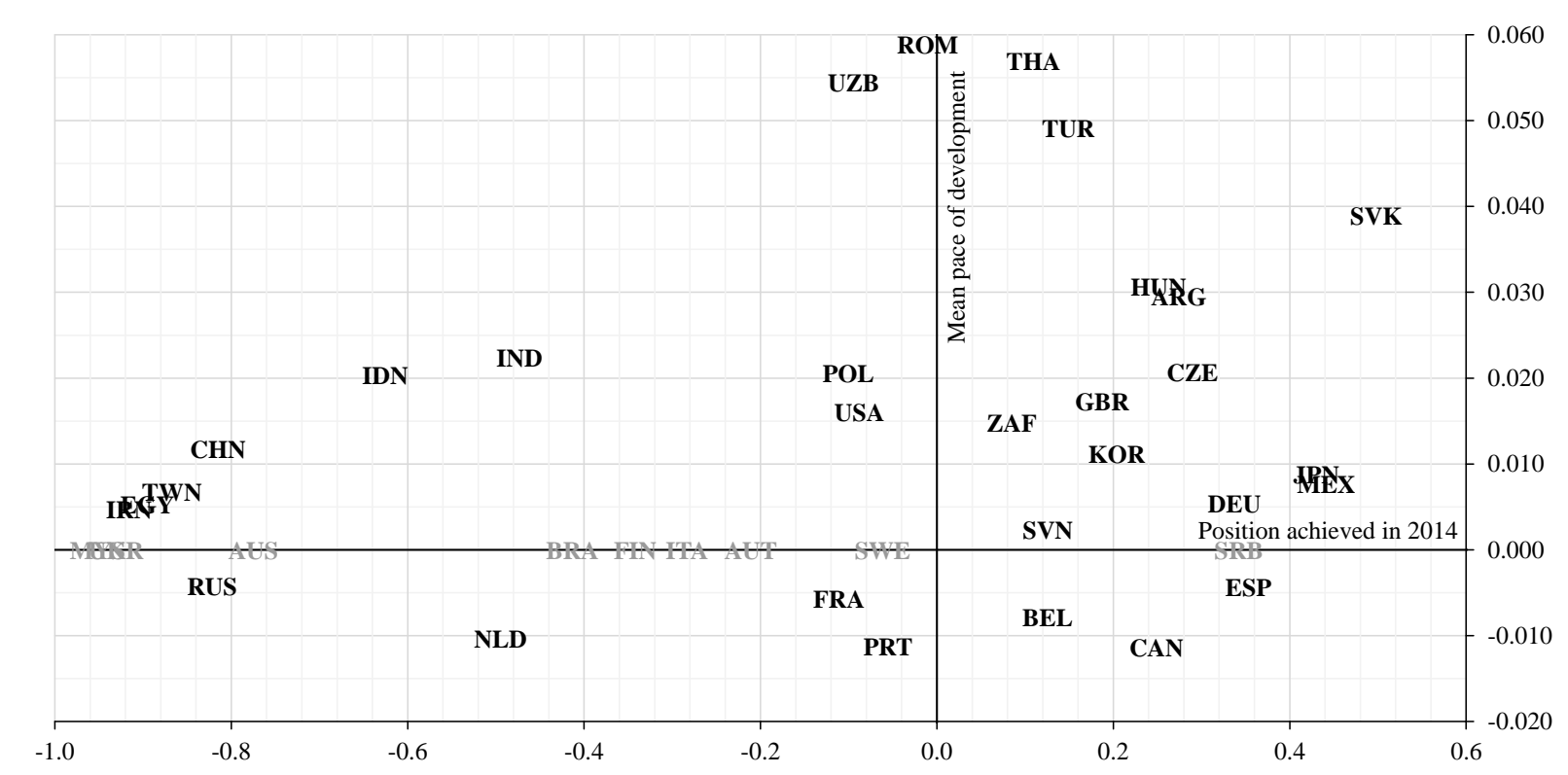

Note: Countries with statistically insignificant trend of development are depicted in gray on the horizontal axis. For country codes see the Tab. 1.

Source: own, based on data from [21]

Fig. 4: Shifts in comparative advantages in manufacturing of motor vehicles

The Fig. 4 indicates several interesting facts:

1) From the traditional, West European automobile producers only Germany and the United Kingdom experienced a positive development in the competitiveness of their car industries in the last two decades. This has translated to a shrinking share of West European countries on the global car production (from 67\% in 2000 to $61 \%$ in 2014). The Netherlands, France, Portugal, Belgium, and Spain faced significant deterioration of their comparative advantages in car production. In France and Belgium, the car production in 2014 was lesser by almost a half compared to the output in 2000, in Italy even more, by nearly $60 \%$.

2) Within the European Union the new member countries, especially Slovakia, the Czech Republic, Hungary, Romania, and Poland experienced a significant improvement of their car production competitiveness. In fact, Slovakia proved to be the most competitive global automobile producer. Romania was the fastest catching-up country and the Czech Republic is nowadays producing $7 \%$ of all EU motor vehicles.

3) Also the developing countries are slowly but continuously improving their comparative advantages in car production. While changes in Iran, Egypt, Taiwan, and China are rather slow and the export potential of their car producers is still rather low, India, Indonesia, and especially Uzbekistan are quickly trying to catch up with the group of successful emerging markets consisting of Turkey, Argentina, the South Africa, and Mexico.

4) The position of the United States and Canada has been weakened by Japanese and South Korean competitors and complicated by the progressive emerging markets. While the USA still fight, although the competitiveness of their car industry is not in a very good shape, the Canadian automobile producers are working hard to set off the losses caused by the $2007-2008$ crisis.

The general trend is the gradual transfer of the production to more favourable conditions and to cheaper production locations. While in the 1980's Europe, the USA, and Japan produced more than $90 \%$ of the world's vehicles, today their share shrank well below $45 \%$. Within the EU, the production has been transferred from countries in Western and Southern Europe to 
geographically convenient new EU members. This process is obviously associated with reductions in production in the traditional countries of western and southern EU, including reduction of jobs and employment capacities. The remaining question is the future development in the distribution of production, given the potential increase in production costs in the eastern EU countries. It seems obvious, that the car producers would like to move their production plants to even cheaper, but still reliable and predictable economies [12].

\section{Conclusion}

Significant increase in car production in developing countries and emerging markets provides an opportunity for the EU automotive industry, but also creates a strong pressure to improve its sustainability and to withstand the growing global competition. In the EU, the automotive industry provides 13 million jobs and as such has a crucial importance for the economic growth and employment. As a remarkable innovator, the automotive industry is also a giant investor in research and development. In 2011, the EU car producers only invested 32 million euro, which exceeds both the pharmaceutical industry and even the biotechnology sectors [1]. The automotive industry is propelled by innovation: innovation in production (better fuel efficiency, aluminum bodies of cars, computer technologies and safety systems built in cars, etc.), innovation in financing and sales (e.g. offering operational leasing instead of purchase), innovation in advertising (the auto industry spend globally about 100 billion euro on advertising in 2014).

The aim of the EU is to maintain a world-class automotive industry producing the most energy-efficient and safe vehicles and guarantee millions of highly skilled jobs. In order to achieve these objectives, the European Commission has created CARS 2020 Action Plan aimed at strengthening the competitiveness and sustainability of this sector by 2020 [7]. The European Commission proposes massive innovative stimulus through streamlining research and development within the framework of the "European Green Cars Initiative". The proposed measures deal with exhaust emissions, alternative fuels, funding for research and development, improving the road safety, and the development of intelligent transport systems. At the same time, the Commission addresses the problems associated with low demand for cars and focuses on excessive and unused factory capacity in the EU (e.g. Fiat capacity utilization was around $55 \%$ in 2013, Peugeot operated at $66 \%$ of their capacity) [12]. The second pillar consists of the initiatives and aims to improve market conditions. The main objective is to strengthen the competitiveness of the automotive industry within the EU and to ensure appropriate, reliable, and predictable conditions for undertaking through regulatory policies [15]. The third pillar aims at strengthening the competitiveness of the EU on the world markets through effective trade policy and international harmonization of vehicle regulations. Because of sluggish demand for cars in the EU, is seems crucial to find and penetrate new markets, especially in fast-growing developing countries [7]. The fourth pillar is focused on anticipating the needs of adaptation through investment in human capital and skills to mitigate the social impact of restructuring. Within this pillar, the Commission set the goal to propose the measures needed to solve the problems with unused production capacities and to stimulate demand without violating the principles of the internal market and competition [15].

The efficiency and fruitfulness of the CARS 2020 Action Plan as well as a deeper analysis of changes and shifts in the sector of manufacturing of bodies for motor vehicles, trailers, and semi-trailers, and manufacturing of parts and accessories for motor vehicles and complex assessment of their results remain subjects of our future research. 


\section{Acknowledgements}

This article is a part of a wider research project "Transformations of the European Union in the Context of Global Changes of a Political and Economic Nature" supported by the Metropolitan University Prague.

\section{Literature}

[1] ACEA: The Automobile Industry Pocket Guide 2014 - 2015. [online]. 2014. [accessed 2015-06-27]. Available from http://www.acea.be/uploads/publications/POCKET_GUIDE_2014-1.pdf

[2] BALASSA, B.: Trade Liberalization and Revealed Comparative Advantage. Manchester School of Economic and Social Studies. 1965, Vol. 33, Issue 2, pp. 99-123. ISSN 0025-2034.

[3] BARATTIERI, A.: Comparative Advantage, Service Trade, and Global Imbalances. Journal of International Economics. 2014, Vol. 92, Issue 1, pp. 1-13. ISSN 0022-1996.

[4] BERKOWITZ, D.; MOENIUS, J.; PISTOR, K.: Trade, Law, and Product Complexity. Review of Economics and Statistics. 2006, Vol. 88, Issue 2, pp. 363-373. ISSN 00346535 .

[5] CHOR, D.: Unpacking Sources of Comparative Advantage: A Quantitative Approach. Singapore Management University Economics \& Statistics Working Paper Series. 2008, Vol. 46, Issue 13, pp. 1-47.

[6] DALUM, B.; LAURSEN, K.; VILLUMSEN, G.: Structural Change in OECD Export Specialisation Patterns: De-specialisation and 'Stickiness'. International Review of Applied Economics. 1998, Vol. 12, Issue 3, pp. 447-467. ISSN 0269-2171.

[7] EUROPEAN COMMISSION: CARS 2020: za silný, konkurenceschopný a udržitelný evropský automobilový průmysl. [online]. 2012. [accessed 2015-06-27]. Available from WWW: http://europa.eu/rapid/press-release_IP-12-1187_cs.htm

[8] EUROSTAT: Index of Correspondence Tables. [online]. 2015. [accessed 2015-06-20]. Available from WWW: http://ec.europa.eu/eurostat/ramon/relations/index.cfm?TargetUrl=LST_REL

[9] EUROSTAT: Statistical Classification of Economic Activities in the European Community, Rev. 2. [online]. 2008. [accessed 2015-06-26]. Available from WWW: http://ec.europa.eu/eurostat/statisticsexplained/index.php/Manufacture_of_motor_vehicles,_trailers_and_semitrailers_statistics_-_NACE_Rev._2

[10] GRUPP, H.: The Measurement of Technical Performance of Innovations by Technometrics and Its Impact on Established Technology Indicators. Research Policy. 1994, Vol. 23, Issue 2, pp. 175-193. ISSN 0048-7333.

[11] HINDLS, R.; HOLMAN, R.; HRONOVÁ, S.: Ekonomický slovnik. Praha: C.H.Beck, 2003. ISBN 80-7179-819-3.

[12] KALLSTROM, H.: Why Growth Shifted in the Global Automotive Industry? [online]. Market Realist. 2015. [accessed 2015-06-12]. Available from WWW: http://marketrealist.com/2015/02/shift-growth-global-automotive-industry/ 
[13] MARGAN, F.: Competitiveness in the EU on the Context of the Globalised Economy. In: Proceedings of the $1^{\text {st }}$ International Conference on European Integration 2012. Ostrava: VSB-TU Ostrava, 2012, pp. 188-198. ISBN 978-80-248-2685-1.

[14] MOENIUS, J.: Measuring Comparative Advantage: A Ricardian Approach. [online] University of Redlands: Redlands, CA, USA, 2006. [accessed 2015-06-15]. Available from

WWW: http://bulldog2.redlands.edu/fac/johannes_moenius/content/Index2_new.pdf

[15] MPO ČR: CARS 2020: Akční plán pro konkurenceschopný a udržitelný automobilový prümysl v Evropě. [online]. 2012. [accessed 2015-06-27]. Available from WWW: http://www.mpo.cz/dokument141028.html

[16] OICA: Production Statistics. [online]. 2015. [accessed 2015-06-25]. Available from WWW: http://www.oica.net/wp-content/uploads//total-2014-Q4.pdf

[17] OUTRATA, R.: Comparative Analysis of Competitiveness of Selected New EU Member Countries. Ekonomický časopis. 2012, Vol. 60, Issue 4, pp. 371-387. ISSN 0013-3035.

[18] PINGYAO, L.; JINGYUN, W.: Opportunities and Challenges Faced by the Cooperation of BRICS. Statistical Research. 2012, Vol. 29, Issue 2, pp. 21-27. ISSN 1002-4565.

[19] SIGGEL, E.: International Competitiveness and Comparative Advantage: A Survey and a Proposal for Measurement. Journal of Industry, Competition and Trade. 2006, Vol. 6, Issue 2, pp. 137-159. ISSN 1566-1679.

[20] STATISTA: Worldwide automobile production from 2000 to 2014 (in million vehicles). [online]. 2015. [accessed 2015-06-25]. Available from WWW: http://www.statista.com/statistics/262747/worldwide-automobile-production-since$\underline{2000 /}$

[21] UNCTAD: UNCTADStat. [online] United Nations Conference on Trade and Development: Geneve, Switzerland, 2015. [accessed 2015-06-10]. Available from WWW: http://unctadstat.unctad.org/wds/ReportFolders/reportFolders.aspx?sCS_ChosenLang=e $\underline{\mathrm{n}}$

[22] WANLING, C.; XIAOHUI, W.: A Quantitative Analysis of the Trade Relationship among the BRICS Countries. Comparative Economic \& Social Systems. 2013, Vol. 29, Issue 1, pp. 62-73. ISSN 1003-3947. 


\section{AUTOMOBILOVÝ PRŮMYSL V EVROPSKÉ UNII A JEHO KONKURENCESCHOPNOST}

\section{VE SVĚTĚ}

V poslední dekádě byl automobilový průmysl jedním z nejrychleji rostoucích průmyslových oborů. Stal se rovněž jedním z nejvýznamnějších odvětví hospodářství Evropské unie, prodělal ovšem také řadu strukturálních a teritoriálních přesunů. Právě z těchto důvodů je na místě prověřit konkurenceschopnost automobilového průmyslu na národní úrovni, analyzovat dlouhodobé vývojové trendy v EU, dát je do globálního kontextu, načrtnout pravděpodobné změny v nejbližší budoucnosti a upozornit na potenciální hrozby. Článek využivá metod statistické analýzy vývoje symetrických indexů projevených komparativních výhod k hledání trendů určujících podobu automobilového průmyslu v EU. Autoři poukazují na přesuny konkurenceschopnosti od tradičních západoevropských producentů automobilů ve prospěch nových členských států EU, ale také od USA a Kanady ve prospěch nových, rychle rostoucích rozvojových zemí. Stručný nástin reakce Evropské komise na uvedené proměny automobilového průmyslu v podobě Akčního plánu CARS 2020 nabízí závěrečná část článku.

\section{DIE AUTOMOBILINDUSTRIE IN DER EUROPÄISCHEN UNION UND DEREN KONKURRENZFÄHIGKEIT IN DER WELT}

In der letzten Dekade war die Automobilindustrie eine der am schnellsten wachsenden Industriebranchen. Sie wurde gleichfalls zu einer der bedeutendsten Wirtschaftsbranchen der Europäischen Union. Sie hat indes auch eine Reihe struktureller und territorialer Verschiebungen durchgemacht. Eben aus diesen Gründen ist es angebracht, die Konkurrenzfähigkeit der Automobilindustrie auf nationalem Niveau zu überprüfen, langfristige Entwicklungstrends in der EU zu analysieren, diese in einen globalen Kontext einzubetten, wahrscheinliche Veränderungen in der nächsten Zukunft zu skizzieren und auf potenzielle Bedrohungen aufmerksam zu machen. Dieser Artikel nutzt die Methoden der statistischen Analyse der Entwickung der symmetrischen Indexe der erwiesenen komparativen Vorteile zur Trendsuche, welche die Form der Automobilindustrie in der EU bestimmen. Die Autoren weisen auf Verschiebungen der Konkurrenzfähigkeit von den traditionellen westeuropäischen automobiloproduzenten $\mathrm{zu}$ Gunsten der neuen Mitgliedsstaaten der EU sowie von den USA und Kanada zu Gunsten der neuen, sich schnell wachsenden Entwickungsländer hin. Der letzte Teil des Artikels bringt einen kurzen Abriss der Reaktion der Europäischen Kommission auf die angeführten Veränderungen der Automobilindustrie in Form des Aktionsplans CARS 2020.

\section{PRZEMYSŁ MOTORYZACYJNY W UNII EUROPEJSKIEJ I JEGO KONKURENCYJNOŚĆ W SKALI ŚWIATOWEJ}

Celem artykułu jest zidentyfikowania trendów określających kształt przemysłu motoryzacyjnego w UE, w opracowaniu wykorzystano metody statystycznej analizy rozwoju wskaźników symetrii ujawnionych korzyści komparatywnych. Autorzy wskazują na przesunięcia konkurencyjności od tradycyjnych zachodnioeuropejskich producentów samochodów na korzyść nowych państw członkowskich UE, jak również od USA i Kanady w stronę nowych, szybko wzrastających państw rozwijających się. W zakończeniu artykułu przedstawiono krótki opis reakcji Komisji Europejskiej na wymienione przekształcenia przemysłu motoryzacyjnego w postaci Planu Działania CARS 2020. 